\title{
The Hydrolysis Mechanism of Inulin and Its Hydrolysate in the Reaction Field by the Hot Compressed Water
}

\author{
Naoto Shimizu, Tetsuya UshiYama and Takanori IтоH \\ Graduate School of Agriculture, Hokkaido University, Kita 9 Nishi 9, Kita-ku, Sapporo, Hokkaido 060-8589, Japan \\ Research Faculty of Agriculture, Hokkaido University, Kita 9 Nishi 9, Kita-ku, Sapporo, Hokkaido 060-8589, Japan
}

(Received December 16, 2018; Accepted May 3, 2019)

\begin{abstract}
Aiming to produce functional oligosaccharides such as di-D-fructose dianhydrides (DFAs) from inulin in subcritical water (the hot compressed water), the hydrolysis mechanism of inulin was investigated. The hydrolysis of inulin was conducted in carbon dioxide-the hot compressed water $\left(\mathrm{CO}_{2}-\mathrm{HCW}\right)$ created with a batch-type reactor (temperature: $100^{-}$ $150^{\circ} \mathrm{C}$, pressure: $3.0^{-}-5.0 \mathrm{MPa}$ ). The inulin hydrolysate prepared with $\mathrm{CO}_{2}-\mathrm{HCW}$ were determined by electrospray ionization mass spectrometry and UV-Vis spectroscopy. The results showed that inulin is hydrolyzed to monosaccharides, disaccharides, fructooligosaccharides , and DFAs with $\mathrm{CO}_{2}-\mathrm{HCW}$. The hydronium ion concentration $\left(\left[\mathrm{H}^{+}\right]\right)$formed in $\mathrm{CO}_{2^{-}}$ $\mathrm{HCW}$ was approximately estimated 100 -fold higher than $\left[\mathrm{H}^{+}\right]$created in the hot compressed water without $\mathrm{CO}_{2}$. High $\left[\mathrm{H}^{+}\right]$ is believed to be one of the factors that contributes to the hydrolysis of inulin $<150{ }^{\circ} \mathrm{C}$. The generation of 5hydroxymethylfurfural (HMF) occurred by intramolecular dehydration of fructose was suppressed due to low temperature process $\left(<150^{\circ} \mathrm{C}\right) . \mathrm{CO}_{2}-\mathrm{HCW}$ is one of the means to convert inulin into DFAs while suppressing the generation of $\mathrm{HMF}$.
\end{abstract}

Keywords : carbon dioxide, di-D-fructose anhydrides, electrospray ionization mass spectrometry, hydronium ion, inulin, the hot compressed water

\section{INTRODUCTION}

Chicory (Cichorium intybus L.) is investigated to produce in Tokachi district, Hokkaido, Japan or some plant factories. The roots of chicory contain inulin; it is polysaccharide composed of $\beta$-(2,1)-linked $\beta$-D-fructofuranosyl residues and terminated with $\alpha$-D-glucopyranosyl unit through $\alpha-(1,2)$ glycosidic linkage. In plants, it is principally biosynthesized from sucrose and is one of the principal stored forms of energy. Inulin is the raw material of functional oligosaccharides such as di-D-fructose dianhydrides (DFAs) that can be used as low-caloric sweeteners with low cariogenicity and prebiotic properties (Minamida et al., 2004; 2005a; 2005b; Mitamura and Hara, 2005; Minamida et al., 2006; Yoshimoto et al., 2013) and may also increase the absorption of essential minerals (Shigematsu et al., 2004; Hara et al., 2010; Nakamori et al., 2010), flavonoids (Matsumoto et al., 2007). The techniques for converting inulin into DFAs are almost performed with enzymatic reactions (Uchiyama et al., 1973; Haraguchi et al., 1988; Kawamura et al., 1988; Yokota et al., 1991; Cho et al., 1996; Park and Choi, 1996; Kang et al., 1998; Haraguchi et al., 2002; 2005; 2006; Zhao et al., 2011; Wang et al., 2015). The DFA producing microorganisms were summarized, 30 microbial strains have been isolated to produce DFAs via enzymatic reaction, but only four isomers have been obtained by means of this, including DFA III, DFA I, DFA IV and DFA V (Wang et al., 2015). While the reactions are highly selectivity and proceed in mild temperature, culturing bacteria and purification of enzymes are the essential process and might be the bottleneck for manufacturing DFAs in enzymatic reactions.

The application of subcritical fluids reaction fields in food processing have attracted much attention due to their unique ability. The hot compressed water, heated to $100^{-}$ $374^{\circ} \mathrm{C}$ and pressurized to state liquid phase (Savage, 1999), is one of subcritical fluids reaction fields and is most commonly used medium because water is abundant and nontoxicity. It has characteristic to hydrolysis the substances without any catalyst due to increase of ion product of water $\left(K_{\mathrm{w}}=\left[\mathrm{H}^{+}\right]\left[\mathrm{OH}^{-}\right]\right)$. In some cases, the inert gas such as nitrogen gas or carbon dioxide gas are used for pressurizing water in a batch-type reactor. Here, we call the reaction field pressurized with nitrogen gas $\mathrm{N}_{2}$-the hot compressed water $\left(\mathrm{N}_{2}-\mathrm{HCW}\right)$ or pressurized with carbon dioxide gas $\mathrm{CO}_{2}$-the hot compressed water $\left(\mathrm{CO}_{2}-\mathrm{HCW}\right)$. Nitrogen gas is not related to the reaction in $\mathrm{N}_{2}-\mathrm{HCW}$, so the reaction occurred in $\mathrm{N}_{2}-\mathrm{HCW}$ is the only effect of water. On the other hands, $\mathrm{CO}_{2}-\mathrm{HCW}$ is known to accelerate the acidcatalyzed reaction by the high-pressure $\mathrm{CO}_{2} / \mathrm{H}_{2} \mathrm{O}$ technology (Morais et al., 2014). $\mathrm{CO}_{2}$ dissolved in water creates carbonic acid whose value of acid dissociation constant $\left(\mathrm{p} K_{\mathrm{a}}\right)$ is lower than the that of $\mathrm{p} K_{\mathrm{a}}$ of water and generates the hydronium ions easily (Hunter and Savage, 2003; 2008). The acid-catalyzed reaction accelerated by $\mathrm{CO}_{2}-$ HCW would bring about two benefits. Firstly, the reactions conducted with $\mathrm{CO}_{2}-\mathrm{HCW}$ are expected to proceed in rela- 
tively low temperature compared with $\mathrm{N}_{2}-\mathrm{HCW}$. This would lead to control the reaction rigidly in terms of reducing by-products which produced at high temperature range. Secondly, $\mathrm{CO}_{2}-\mathrm{HCW}$ does not require the acids such as sulfuric acid or hydrochloric acid that are needed to be neutralized with base after the reaction. In addition, $\mathrm{CO}_{2}$ dissolved in water can be recycled as depressurizing the reaction fields.

Previously, we prepared the inulin hydrolyzate solutions containing DFAs with $\mathrm{N}_{2}-\mathrm{HCW}$ at $160-170^{\circ} \mathrm{C}$, however, those solutions also contain 5-hydroxymethylfurfural (HMF) (Itoh and Shimizu, 2014). HMF is generated from hexose with the thermal decomposition or high-temperature treatment such as pyrolysis or hydrothermal processing. Although HMF is considered to be valuable intermediate for fine chemicals and liquid fuels (Mukherjee et al., 2014), its separation and purification are complicated. Considering the purification and drying process after the preparation of DFAs, it is desirable to suppress the generation of HMF during preparation. Almost all the reaction of hexose to HMF depends on the preparation temperature of intramolecular dehydration, which means the lower temperature preparation might be the key factor to suppress the generation of HMF. The goal of the current study is to convert inulin into DFAs using $\mathrm{CO}_{2}-\mathrm{HCW}$ preparation at lower temperature $\left(<150^{\circ} \mathrm{C}\right)$ so as to suppress the generation of HMF and reveal the hydrolysis mechanism of inulin with $\mathrm{CO}_{2}$-HCW by electrospray ionization mass spectrometry (ESI-MS), UV-Vis spectroscopy and estimation for the hydronium ion concentration $\left(\left[\mathrm{H}^{+}\right]\right)$.

\section{MATERIALS AND METHODS}

Preparation of the inulin hydrolyzate solutions with the hot compressed water fluids

The experimental procedure was similar to a method published previously (Itoh and Shimizu, 2014; Yoshioka and Shimizu, 2014) and described below. We used Orafti HP, a chicory inulin containing long fructosyl chains with an average degree of polymerization (DP) of over 23 (DKSH Japan KK, Tokyo, Japan). The hydrolysis of inulin was performed in a batch-type reactor equipped with a pressure-resistant vessel made from SUS-316 stainless steel and an inner container made from Teflon and equipped with a type- $\mathrm{K}$ thermocouple and a pressure gauge. Inulin $(0.1 \mathrm{~g})$, distilled water $(10 \mathrm{~mL})$ and a magnetic stir bar were putted into the inner container and the vessel was pressurized to the appropriate pressure with nitrogen gas $\left(\mathrm{N}_{2}-\mathrm{HCW}\right.$ preparation) or carbon dioxide gas $\left(\mathrm{CO}_{2}-\mathrm{HCW}\right.$ preparation). The vessel was tightly closed and then heated and stirred at 1,000 rpm in an organic synthesizer (Chemi Station TM PPV-3000, Tokyo Rikakikai Co., Ltd., Tokyo, Japan) to the appropriate temperature, then held at the required temperature for 15 minutes. The temperature inside the vessel was monitored at 1 second intervals by using the type- $\mathrm{k}$ thermocouple. The temperature of the heating block and the pressure inside the vessel were monitored every 5 minutes. The temperature and the pressure changes in the $\mathrm{HCW}$ processes $\left(\mathrm{CO}_{2}-\mathrm{HCW}\right.$ and

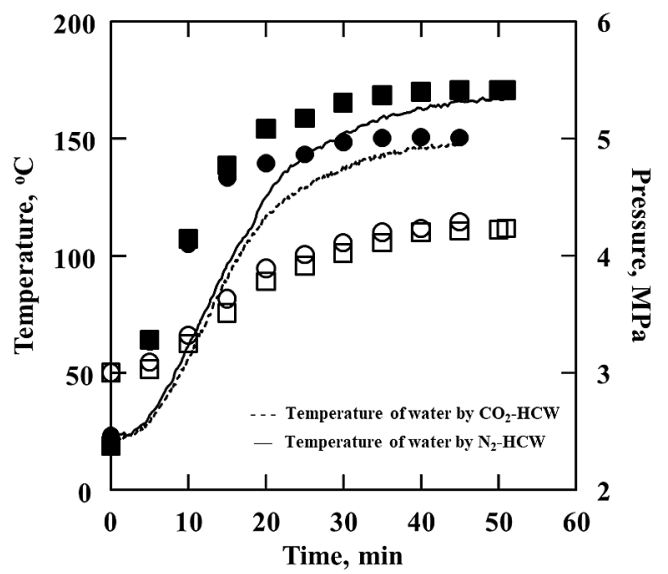

Fig. 1 The change of temperature and pressure during the preparations. The temperature of the water (- - ) $\mathrm{CO}_{2}$ $\mathrm{HCW}$ or $(-) \mathrm{N}_{2}-\mathrm{HCW}$, the temperature of heat block (๑) or ( $\square)$ and the pressure in the vessel $(\bigcirc)$ or $(\square)$. Circles and squares represent the preparation of $\mathrm{CO}_{2}-$ $\mathrm{HCW}$ and $\mathrm{N}_{2}-\mathrm{HCW}$, respectively.

$\mathrm{N}_{2}-\mathrm{HCW}$ ) was shown in Fig. 1. When the preparation was complete, the reaction was quenched by rapidly cooling the vessel with cooled water $\left(5^{\circ} \mathrm{C}\right)$. The resulting inulin hydrolyzate solutions were collected in the glass vials and were kept at $5^{\circ} \mathrm{C}$ until they were analyzed.

Electrospray ionization mass spectrometry (ESI-MS)

The inulin hydrolyzate solutions were analyzed by using a mass spectrometer (Exactive; Thermo Fisher Scientific K.K., Kanagawa, Japan) equipped with an electrospray ionization (ESI) probe. The inulin hydrolyzate solutions were diluted with methanol. The ESI-MS experiments was performed in the negative-ion mode with scanning over the range of mass-to-charge ratios $(\mathrm{m} / \mathrm{z}) 150^{-}$ 2,000 . The following instrument settings were used: spray voltage $2.6 \mathrm{kV}$, sheath gas pressure 30 arbitrary units (a.u.), auxiliary nitrogen pressure 15 a.u., capillary temperature $300^{\circ} \mathrm{C}$; heater temperature $250^{\circ} \mathrm{C}$, capillary voltage $-27.5 \mathrm{~V}$, tube lens voltage $-110 \mathrm{~V}$, skimmer voltage $-45 \mathrm{~V}$.

\section{UV-Vis spectroscopy}

UV-Vis spectra of the inulin hydrolyzate were recorded on a UV-Vis spectrometer (V-560, Jasco Co., Ltd., Tokyo, Japan) in the wavelength range of 200 to 900 $\mathrm{nm}$. The inulin hydrolyzate solutions $(0.1 \mathrm{~mL})$ were diluted with distilled water $(4.9 \mathrm{~mL})$ then the diluted solutions $(4.0$ $\mathrm{mL}$ ) were poured into the standard cell made from synthetic quartz glass (S10, GL Sciences Inc., Tokyo, Japan).

Estimation of the hydronium ion concentration in the hot compressed water

Assuming hydronium ion $\left(\mathrm{H}^{+}\right)$and hydroxide ion $\left(\mathrm{OH}^{-}\right)$were ionized equally in the hot compressed water, $\left[\mathrm{H}^{+}\right]$was represented from equation (1) using the ion product of water $\left(K_{\mathrm{w}}=\left[\mathrm{H}^{+}\right]\left[\mathrm{OH}^{-}\right]\right)$,

$$
\left[\mathrm{H}^{+}\right]=K_{\mathrm{W}}{ }^{1 / 2}
$$

where the bracket represents the molal concentration. $K_{\mathrm{w}}$ was calculated from Marshall and Franck equation (Marshall and Franck, 1981), as shown below, 
$\log K_{\mathrm{w}}=A+B / T+C / T^{2}+D / T^{3}+\left(E+F / T+G / T^{2}\right) \cdot \log \rho_{\mathrm{w}}$

where $T$ is the absolute temperature of water $(\mathrm{K}), \rho_{\mathrm{w}}$ is the density of water $\left(\mathrm{g} / \mathrm{cm}^{3}\right)$, and the constants are: $A=-4.098$ $(-), B=-3,245.2(\mathrm{~K}), C=2.2362 \times 10^{5}\left(\mathrm{~K}^{2}\right), D=-3.984 \times$ $10^{7}\left(\mathrm{~K}^{3}\right), E=13.957(-), F=-1,262.3(\mathrm{~K}), G=8.5641 \times 10^{5}$ $\left(\mathrm{K}^{2}\right)$. The density of water was obtained from the NIST online chemistry web book (NIST, 2015). $\left[\mathrm{H}^{+}\right]$in $\mathrm{N}_{2}$ - HCW were estimated from equation (1) and (2).

$\left[\mathrm{H}^{+}\right]$in $\mathrm{CO}_{2}-\mathrm{HCW}$ was estimated by the square root of the quantity of $K_{\mathrm{w}}$ plus a member of the contribution of $\mathrm{CO}_{2}$ (Hunter and Savage, 2003;2008), as shown below,

$$
\left[\mathrm{H}^{+}\right]=\left(K_{\mathrm{w}}+K_{\mathrm{a} 1} K_{\mathrm{H}} P_{\mathrm{CO}_{2}}\right)^{1 / 2}
$$

where $K_{\mathrm{a} 1}, K_{\mathrm{H}}$, and $P_{\mathrm{CO}_{2}}$ represent the first ionization constant of carbonic acid (mol/kg), the Henry's law constant of carbon dioxide dissolved in water $(\mathrm{mol} /(\mathrm{kg} \mathrm{MPa}))$ and the pressure of carbon dioxide $(\mathrm{MPa})$, respectively. $K_{\mathrm{a} 1}$ was obtained from model 1 of Patterson et al. (Patterson et al., 1982), $K_{\mathrm{H}}$ was taken from Hunter and Savage (Hunter and Savage, 2008), and $P_{\mathrm{CO}_{2}}$ was obtained from the pressure gage at reaction end.

\section{RESULTS AND DISCUSSION}

\section{Electrospray ionization mass spectrometry}

ESI-MS spectra (negative-ion mode) of the inulin hydrolyzate prepared by using $\mathrm{CO}_{2}-\mathrm{HCW}$ are shown in Fig. 2. The inulin hydrolyzate prepared at $100^{\circ} \mathrm{C}$ showed ions at $m / z=179,341,503,665,827,989,1,151,1,313$, 1,475, 1,637, 1,799 and 1,961 (Fig. 2(a) and 2(b)). Monosaccharides such as fructose (fr) or glucose (g) were observed at $m / z=179\left([\mathrm{fr}-\mathrm{H}]^{-}\right.$or $\left.[\mathrm{g}-\mathrm{H}]^{-}\right)$. Disaccharides such as fructodisaccharides $\left(\mathrm{f}_{2}\right)$ or sucrose $(\mathrm{gf})$ formed the base peak at $m / z \quad 341=\left(\left[\mathrm{f}_{2}-\mathrm{H}\right]^{-}\right.$or $\left.[\mathrm{gf}-\mathrm{H}]^{-}\right)$. Fructooligosaccharides (FOSs) with DPs of 3-12 produced deprotonated ions $\left[\mathrm{f}_{\mathrm{n}}-\mathrm{H}\right]^{-}$or $\left[\mathrm{gf}_{\mathrm{m}}-\mathrm{H}\right]^{-}(3 \leq \mathrm{n} \leq 12,2 \leq \mathrm{m} \leq$ 11) at $m / z=503,665,827,989,1,151,1,313,1,475$, $1,637,1,799$ and 1,961 , respectively. At $110^{\circ} \mathrm{C}$, FOSs with DPs of above $10(=m / z 1,799,1,961)$ were not observe. At $130^{\circ} \mathrm{C}$, disaccharides formed the base peak at $\mathrm{m} / \mathrm{z} 341$ as well as shown in $100^{\circ} \mathrm{C}$, however, FOSs with DPs above 5 $(=m / z$ 827) were not observed. DFAs having a molecular mass of $324 \mathrm{Da}$ also produced ions at $\mathrm{m} / z 323[\mathrm{M}-\mathrm{H}]^{-}$or $647[2 \mathrm{M}-\mathrm{H}]^{-}(\mathrm{M}:$ DFAs $)$ at $130^{\circ} \mathrm{C}$. The cluster ion $[2 \mathrm{M}-\mathrm{H}]^{-}$is observed in ESI-MS when the substances are comparatively high concentration. At $150^{\circ} \mathrm{C}$, DFAs formed the base peak at $m / z 323[2 \mathrm{M}-\mathrm{H}]^{-}$and also produced the cluster ion at $m / z 647[2 \mathrm{M}-\mathrm{H}]^{-}$.

The preparations of $\mathrm{CO}_{2}-\mathrm{HCW}$ at $100^{\circ} \mathrm{C}$ had not influence on the hydrolysis of inulin as a result of the ESI-MS spectra of the inulin hydrolyzate, those including FOSs with DPs of $3^{-12}$. In contrast to $100^{\circ} \mathrm{C}$, the hydrolysis of inulin proceeded to some extent at $130^{\circ} \mathrm{C}$ due to little FOS with $\mathrm{DP}_{\mathrm{S}}$ of above 5. Therefore, the process temperature was found to be an important parameter to conduct the hydrolysis of inulin and effect on the inulin hydrolyzate components. ESI-MS spectrum of the inulin hydrolyze prepared at $150^{\circ} \mathrm{C}$ was very similar to that of DFA III standard as previously reported (Itoh and Shimizu, 2014). This result supports that DFAs are the major products of the hydrolyzate prepared at $150^{\circ} \mathrm{C}$ with $\mathrm{CO}_{2}-\mathrm{HCW}$. The intramolecular dehydration of fructodisaccharides into DFAs occurs at temperatures above $160^{\circ} \mathrm{C}$ with $\mathrm{N}_{2}-\mathrm{HCW}$. In the current study, however, the production of DFAs proceeds
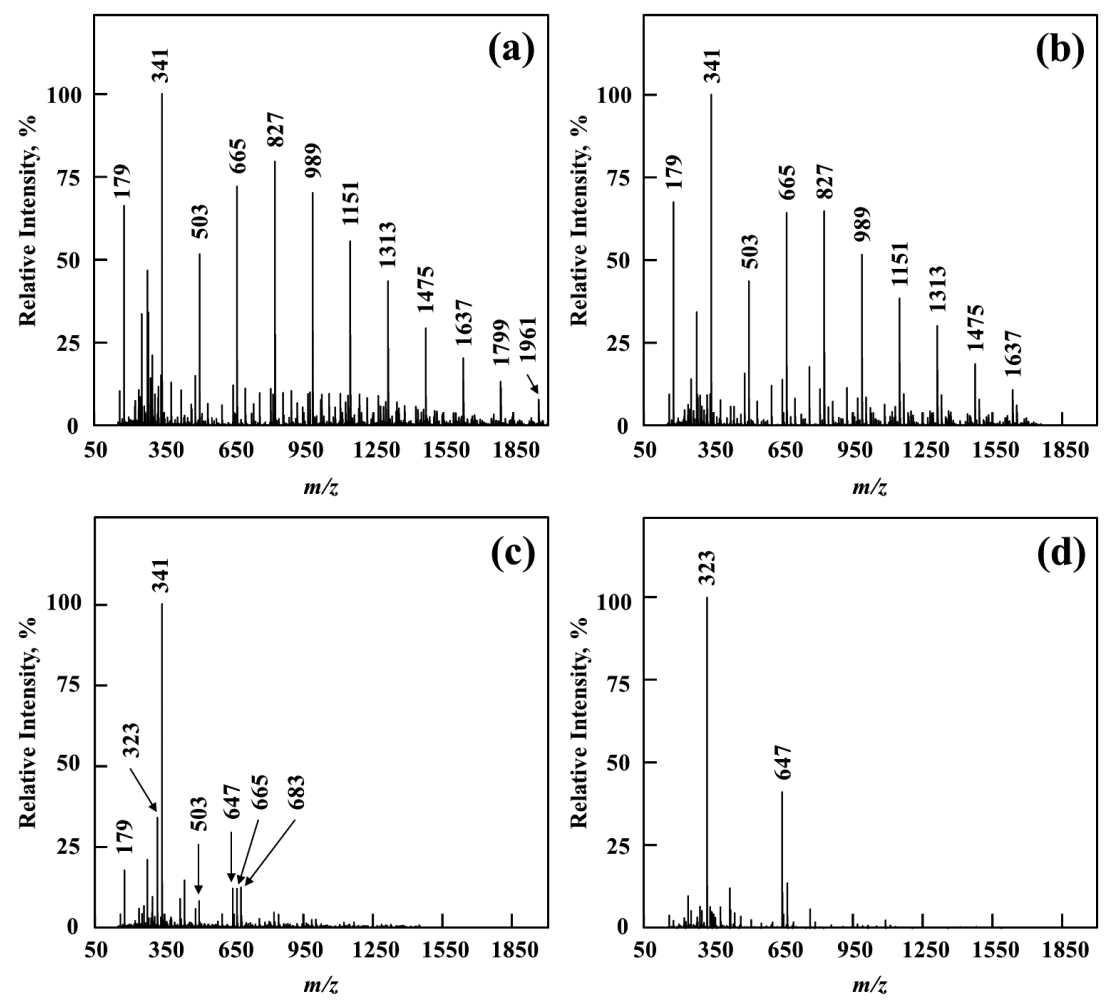

Fig. 2 ESI-MS spectra (negative-ion mode) of the inulin hydrolyzate prepared at (a) $100^{\circ} \mathrm{C}$, (b) $110^{\circ} \mathrm{C},(\mathrm{c}) 130^{\circ} \mathrm{C}$ and $(\mathrm{d}) 150^{\circ} \mathrm{C}$. 

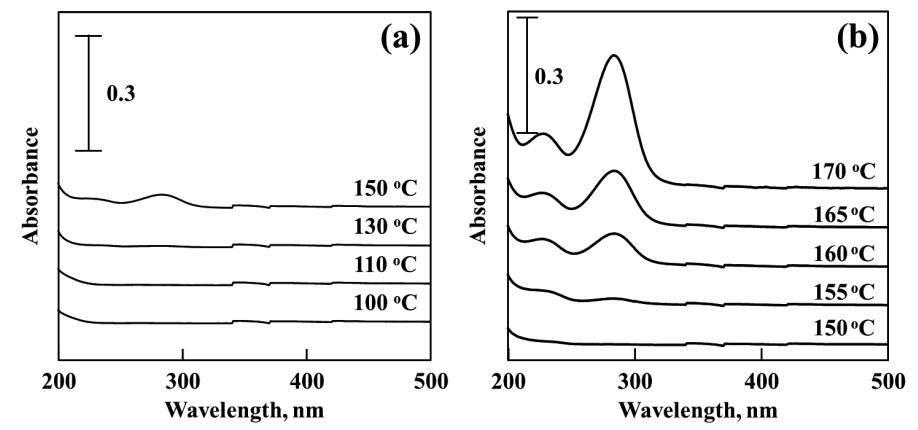

Fig. 3 UV-Vis spectra of the inulin hydrolyzate prepared by (a) $\mathrm{CO}_{2}-\mathrm{HCW}$ or (b) $\mathrm{N}_{2}-\mathrm{HCW}$.

at $150^{\circ} \mathrm{C}$ or less with $\mathrm{CO}_{2}-\mathrm{HCW}$. This is an important result the inert gas changing nitrogen gas to carbon dioxide gas allows to prepare DFAs at $130-150^{\circ} \mathrm{C}$ in subcritical fluid reaction fields.

The difference of $\left[\mathrm{H}^{+}\right]$in each reaction fields have probably influence on the extent of reaction. $\left[\mathrm{H}^{+}\right]$in $\mathrm{CO}_{2}$ $\mathrm{HCW}$ would be expected to be much higher than $\left[\mathrm{H}^{+}\right]$in $\mathrm{N}_{2}-\mathrm{HCW}$. Considering the collision frequency between $\left[\mathrm{H}^{+}\right]$and inulin in each reaction fields, $\left[\mathrm{H}^{+}\right]$created in $\mathrm{CO}_{2}$ - $\mathrm{HCW}$ can easily attack to the $\beta-(2,1)$ glycosidic bonds of inulin. Consequently, the hydrolysis of inulin in $\mathrm{CO}_{2}-\mathrm{HCW}$ proceed at the temperature below $150^{\circ} \mathrm{C}$.

$U V$-Vis spectroscopy

The UV-Vis spectra of the inulin hydrolyzate were shown in Fig. 3. The spectra prepared by $\mathrm{CO}_{2}-\mathrm{HCW}$ at 100,110 and $130^{\circ} \mathrm{C}$ were broad and no peaks were observed (Fig. 3(a)). At $150^{\circ} \mathrm{C}$, the inulin hydrolyzate prepared by $\mathrm{N}_{2}-\mathrm{HCW}$ provided the strong peak at $284 \mathrm{~nm}$ which might be corresponds to HMF or furfural, especially above at $160^{\circ} \mathrm{C}$ (Fig. 3(b)). Furthermore, the absorbance at $284 \mathrm{~nm}$ increased with temperature.

The absorbance at $284 \mathrm{~nm}$ of the inulin hydrolyzate prepared by $\mathrm{N}_{2}-\mathrm{HCW}$ at 160,165 and $170^{\circ} \mathrm{C}$ were higher than that of the ones prepared at 150 and $155^{\circ} \mathrm{C}$. The absorbance depends on the concentration of HMF in the inulin hydrolyzate according to Lambert-Beer law. Thus, the concentration of HMF in the inulin hydrolyzate increases with preparation temperature. In $\mathrm{CO}_{2}-\mathrm{HCW}$, the intramolecular dehydration of fructose into HMF did not appear to proceed at 100,110 , and $130^{\circ} \mathrm{C}$ our experimental condition because of comparatively low temperature preparation, except for the conducted temperature at $130^{\circ} \mathrm{C}$.

The temperature for the intramolecular dehydration of fructose into $\mathrm{HMF}$ seems to be different between $\mathrm{CO}_{2}$ $\mathrm{HCW}$ and $\mathrm{N}_{2}-\mathrm{HCW}$ at $150^{\circ} \mathrm{C}$. This is also believed to be difference of $\left[\mathrm{H}^{+}\right]$in each reaction fields. Because $\left[\mathrm{H}^{+}\right]$in $\mathrm{CO}_{2}-\mathrm{HCW}$ is much higher than $\mathrm{N}_{2}-\mathrm{HCW}$, the fructose as a result of hydrolysis in $\mathrm{CO}_{2}-\mathrm{HCW}$ at $150^{\circ} \mathrm{C}$ is easily attacked from hydronium ions compared to the one occurred in $\mathrm{N}_{2}-\mathrm{HCW}$ at 150 and $155^{\circ} \mathrm{C}$. As a consequence, the intramolecular dehydration into HMF appears to slightly proceed in $\mathrm{CO}_{2}-\mathrm{HCW}$ at $150^{\circ} \mathrm{C}$. However, the absorbance of inulin hydrolysate prepared by $\mathrm{CO}_{2}-\mathrm{HCW}$ at $150^{\circ} \mathrm{C}$ are lower than that of ones prepared by $\mathrm{N}_{2}-\mathrm{HCW}$ at 160,165 and $170^{\circ} \mathrm{C}$. Therefore, $\mathrm{CO}_{2}-\mathrm{HCW}$ can prepare DFAs from inulin with reduction of HMF.
Estimation of the hydronium ion concentration in the hot compressed water

The results of ESI-MS and UV-V is suggested that the ability of hydrolysis for inulin in $\mathrm{CO}_{2}-\mathrm{HCW}$ seems to be high as it was conducted in $\mathrm{N}_{2}-\mathrm{HCW}$. This would be considered that $\left[\mathrm{H}^{+}\right]$in $\mathrm{CO}_{2}-\mathrm{HCW}$ is higher than those in $\mathrm{N}_{2}-\mathrm{HCW}$. Accordingly, we estimated $\left[\mathrm{H}^{+}\right]$in each reaction fields. $\left[\mathrm{H}^{+}\right]$formed in each reaction fields were listed in Table $1 .\left[\mathrm{H}^{+}\right]$ranged from $2.71 \times 10^{-4}$ to $3.87 \times 10^{-4}$ $\mathrm{mol} / \mathrm{kg}$ formed in $\mathrm{CO}_{2}-\mathrm{HCW}$ ranged from $1.53 \times 10^{-6}$ to $1.85 \times 10^{-6} \mathrm{~mol} / \mathrm{kg}$ are approximately 100 -fold higher than that of created in $\mathrm{N}_{2}-\mathrm{HCW}$. The Henry's constant $\left(K_{\mathrm{H}}\right)$ of carbon dioxide which represents solubility of carbon dioxide into water behaves the convex downward and reaches the minimum at temperature around $150^{\circ} \mathrm{C}$ (Hunter and Savage, 2008). For this reason, in $\mathrm{CO}_{2}-\mathrm{HCW}$ at $100-150$ ${ }^{\circ} \mathrm{C}$, the solubility of carbon dioxide into water slightly decrease and $\left[\mathrm{H}^{+}\right]$results in lower with temperature increase. On the other hands, in $\mathrm{N}_{2}-\mathrm{HCW}$ at $150-170^{\circ} \mathrm{C}$, $\left[\mathrm{H}^{+}\right]$increase with temperature due to $K_{\mathrm{w}}$ also increase with temperature. $\left[\mathrm{H}^{+}\right]$in $\mathrm{N}_{2}-\mathrm{HCW}$ cannot reach to the amount of hydronium ions in $\mathrm{CO}_{2}-\mathrm{HCW}$ because the maximum of $K_{\mathrm{w}}$ is about $-11\left[\log K_{\mathrm{w}}(\mathrm{mol} / \mathrm{kg})^{2}\right]$, which means the maximum of $\left[\mathrm{H}^{+}\right]$is about $3.16 \times 10^{-6}$. The intramolecular dehydration of fructose occurred to proceed at $160^{-}$ $170^{\circ} \mathrm{C}$.

The temperature dependence of the absorbance of inulin hydrolyzate at $284 \mathrm{~nm}$ was shown in Fig. 3. In $\mathrm{N}_{2}$ $\mathrm{HCW}$, the absorbance at $284 \mathrm{~nm}$ representing the presence of 5-HMF increase with temperature (Fig. 4 (b)), espe-

Table 1 The hydronium ion concentration at each experiments $\left(T_{\mathrm{p}}\right.$ : preset temperature, $T_{\mathrm{f}}$ : reached temperature, $P_{\mathrm{i}}$ : preset pressure, $P_{\mathrm{f}}$ : reached pressure).

\begin{tabular}{lcrccc}
\hline & $\begin{array}{c}T_{\mathrm{p}} \\
{\left[{ }^{\circ} \mathrm{C}\right]}\end{array}$ & $\begin{array}{c}T_{\mathrm{f}} \\
{\left[{ }^{\circ} \mathrm{C}\right]}\end{array}$ & $\begin{array}{c}P_{\mathrm{i}} \\
{[\mathrm{MPa}]}\end{array}$ & $\begin{array}{c}P_{\mathrm{f}} \\
{[\mathrm{MPa}]}\end{array}$ & $\begin{array}{c}{\left[\mathrm{H}^{+}\right]} \\
{[\mathrm{mol} / \mathrm{kg}]}\end{array}$ \\
\hline \multirow{6}{*}{$\mathrm{CO}_{2}-\mathrm{HCW}$} & 100 & 99.1 & 3.00 & 3.40 & $3.87 \times 10^{-4}$ \\
& 110 & 110.0 & 3.00 & 3.71 & $3.55 \times 10^{-4}$ \\
& 130 & 130.2 & 3.00 & 3.68 & $3.23 \times 10^{-4}$ \\
$\mathrm{~N}_{2}-\mathrm{HCW}$ & 150 & 148.1 & 3.00 & 4.29 & $2.71 \times 10^{-4}$ \\
\hline & 150 & 149.0 & 3.00 & 4.00 & $1.53 \times 10^{-6}$ \\
& 155 & 153.2 & 3.00 & 4.09 & $1.60 \times 10^{-6}$ \\
& 160 & 159.3 & 3.00 & 4.20 & $1.70 \times 10^{-6}$ \\
& 165 & 163.5 & 3.00 & 4.23 & $1.78 \times 10^{-6}$ \\
& 170 & 167.8 & 3.00 & 4.23 & $1.85 \times 10^{-6}$ \\
\hline
\end{tabular}


cially converting inulin into DFAs needs to be treated at higher temperature range $\left(160-170^{\circ} \mathrm{C}\right)$. On the other hands, in $\mathrm{CO}_{2}-\mathrm{HCW}$, the converting inulin into DFAs was attained at $130-150^{\circ} \mathrm{C}$ and the absorbance at $284 \mathrm{~nm}$ is relatively low. HMF is produced by dehydration action of the hot compressed water, i.e., inulin is hydrolyzed to fructose, and then converted into HMF via intramolecular dehydration of fructose (Fig. 4). The low temperature (130-150 ${ }^{\circ} \mathrm{C}$ ) and high $\left[\mathrm{H}^{+}\right]$enable to produce DFAs with suppressing generation of 5-HMF in $\mathrm{CO}_{2}-\mathrm{HCW}$.
In conclusion, we conducted the hydrolysis of inulin with $\mathrm{CO}_{2}-\mathrm{HCW}\left(100-150^{\circ} \mathrm{C}, 3.0^{-5} .0 \mathrm{MPa}\right)$ in a batch-type reactor. The results of ESI-MS and UV-Vis of the inulin hydrolysate showed that inulin was hydrolyzed to FOSs, fructose, HMF and DFAs. The hydrolysis of inulin proceeded at higher temperature and the components of the inulin hydrolyzate varied depending on the preparation temperature. The major products of inulin hydrolysate prepared with $\mathrm{CO}_{2}-\mathrm{HCW}$ at $130-150^{\circ} \mathrm{C}$ were DFAs and the generation of HMF were significantly suppressed. This is
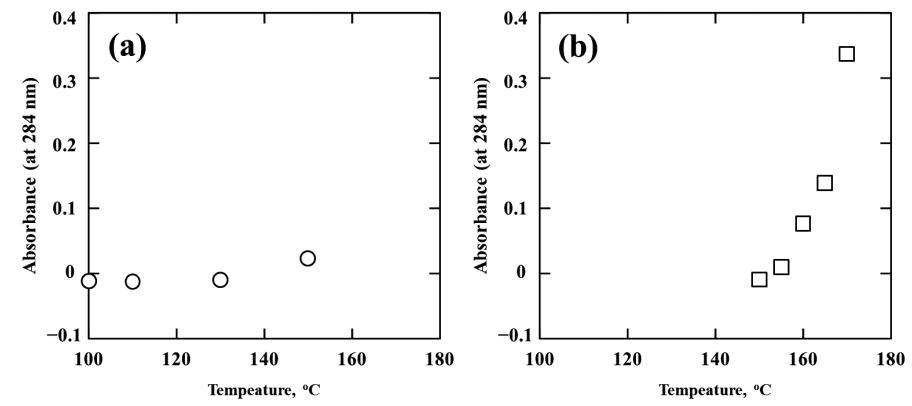

Fig. 4 The temperature dependence of the absorbance at $284 \mathrm{~nm}$. (a) $\mathrm{CO}_{2}-\mathrm{HCW}$, (b) $\mathrm{N}_{2}-\mathrm{HCW}$.

(a)
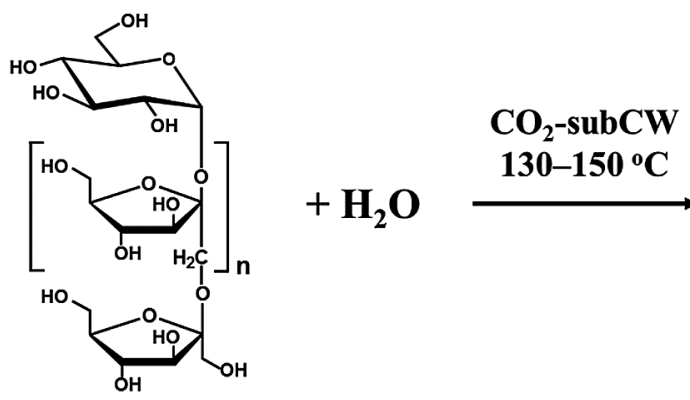

inulin

(b)
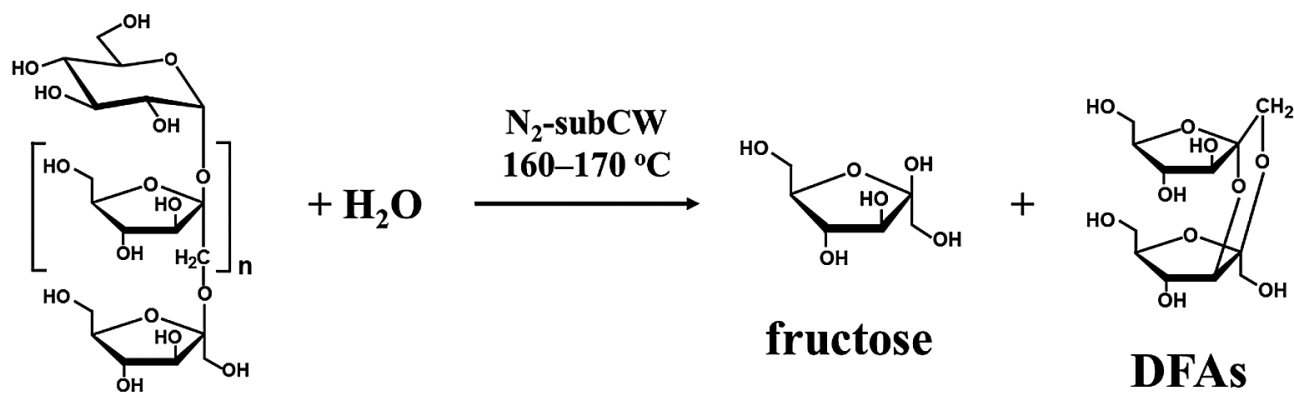

fructose

inulin

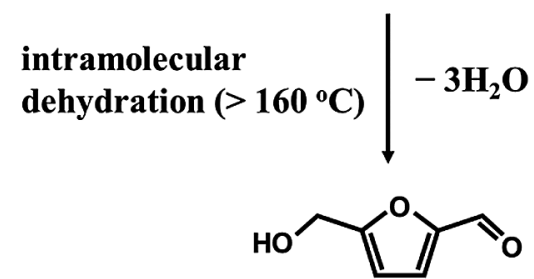

DFAs

\section{HMF}

Scheme 1 The reaction mechanism of hydrolysis of inulin with (a) $\mathrm{CO}_{2}-\mathrm{HCW}$ and (b) $\mathrm{N}_{2}-\mathrm{HCW}$. 
owing to the characteristic of $\mathrm{CO}_{2}-\mathrm{HCW}$ regarding to the high $\left[\mathrm{H}^{+}\right]$(Scheme 1). The estimation of $\left[\mathrm{H}^{+}\right]$and internal energy of each reaction fields revealed that $\left[\mathrm{H}^{+}\right]$created with $\mathrm{CO}_{2}-\mathrm{HCW}$ at temperatures from 130 to $150^{\circ} \mathrm{C}$ were 100 -fold higher than the ones created with $\mathrm{N}_{2}$ - $\mathrm{HCW}$ at 150 ${ }^{\circ} \mathrm{C}$. The current study demonstrated that $\mathrm{CO}_{2}-\mathrm{HCW}$ is one of option of converting inulin into DFAs while suppressing generation of $\mathrm{HMF}$.

\section{REFERENCES}

Cho, C.-M., Lim, Y.-S., Kang, S.-K., Jang, K.-L., Lee, T.-H. 1996. Production of inulin fructotransferase (depolymerizing) from flavobacterium sp. LC-413. J. Food Sci. Nutr. 1: 121-126.

Hara, H., Onoshima, S., Nakagawa, C. 2010. Difructose anhydride III promotes iron absorption in the rat large intestine. Nurtition 26: 120-127.

Haraguchi, K., Kishimoto, M., Seki, K., Hayashi, K., Kobayashi, S., Kainuma, K. 1988. Purification and properties of inulin fructotransferase (depolymerizing) from arthrobacter globiformis C11-1. Agric. Biol. Chem. 52: 291-292.

Haraguchi, K., Yamanaka, T., Ohtsubo, K. 2002. Purification and properties of a heat stable inulin fructotransferase (DFA III-producing) from Arthrobacter pascens T13-2. Carbohydr. Polym. 50: 117-121.

Haraguchi, K., Yoshida, M., Ohtsubo, K. 2005. Thermostable inulin fructotransferase (DFA III-producing) from Arthrobacter sp. L68-1. Carbohydr. Polym. 59: 411-416.

Haraguchi, K., Yoshida, M., Ohtsubo, K. 2006. Inulin fructotransferase (DFA III-producing) from Leifsonia sp. T88-4. Carbohydr. Polym. 66: 75-80.

Hunter, S.E., Savage, P.E. 2003. Acid-catalyzed reactions in carbon dioxide-enriched high-temperature liquid water. Ind. Eng. Chem. Res. 42: 290-294.

Hunter, S.E., Savage, P.E. 2008. Quantifying rate enhancements for acid catalysis in $\mathrm{CO}_{2}$-enriched high-temperature water. AIChE J. 54: 516-528.

Itoh, T., Shimizu, N. 2014. Mass spectrometry of inulin hydrolyzate prepared using subcritical water. Jpn. J. Food Eng. 15: $165-172$.

Kang, S.-I., Kim, W.-P., Chang, Y.-J., Kim, S.-I. $1998 . \quad$ Purification and properties of inulin fructotransferase (DFA III-producing) from Bacillus sp. snu-7. Biosci. Biotechnol. Biochem. 62: 628-631.

Kawamura, M., Takahashi, S., Uchiyama, T. 1988. Purification and some properties of inulin fructotransferase (depolymerizing) from Arthrobacter ilicis. Agric. Biol. Chem. 52: 32093210.

Marshall, W., Franck, E. 1981. Ion product of water substance, $0-1000^{\circ} \mathrm{C}, 1-10,000$ bars. New international formulation and its background. J. Phys. Chem. Ref. Data 10: 295-304.

Matsumoto, M., Matsukawa, N., Chiji, H., Hara, H. 2007. Difructose anhydride III promotes absorption of the soluble flavonoid $\alpha$ G-rutin in rats. J. Agric. Food Chem. 55: 4202-4208.

Minamida, K., Sujaya, I. N., Tamura, A., Shigematsu, N., Sone, T., Yokota, A., Asano, K., Benno, Y., Tomita, F. 2004. The effects of di-D-fructose-1, 2':2, 3'-dianhydride (DFAIII) administration on human intestinal microbiota. J. Biosci. Bioeng. 98: $244-250$.

Minamida, K., Kaneko, M., Ohashi, M., Sujaya, I. N., Sone, T., Wada, M., Yokota, A., Hara, H., Asano, K., Tomita, F. 2005a. Effects of difructose andydride III (DFAIII) administration on bile acids and grownth of DFAIII-assimilating bacterium Ruminocossus products on rat intestine. J. Biosci. Bioeng. 99: 548-554.

Minamida, K., Shiga, K., Sujaya, I. N., Sone, T., Yokota, A., Hara, H., Asano, K., Tomita, F. 2005b. Effects of difructose anhydride III (DFA III) on rat intestinal mocrobiota. J. Biosci. Bioeng. 99: 230-236.

Minamida, K., Asakawa, C., Sujaya, I. N., Kaneko, M., Abe, A., Sone, T., Hara, H., Asano, K., Tomita, F. 2006. Effects of long-term ingestion of difructose anhydride III (DFAIII) on intestinal bacteria and bile acide metabolism in humans. J. Biosci. Bioeng. 101: 149-156.

Mitamura, R., Hara, H. 2005. Prolonged feeding of difructose anhydride III increases strength and mineral concentrations of the femur in ovariectomized rats. Br. J. Nutr. 94: 268-274.

Morais, A. R. C., da Costa Lopes, A. M., Bogel-Lukasik, R. 2014. Carbon dioxide in biomass processing: Contributions to the green biorefinery concept. Chem. Rev. 115: 3-27.

Mukherjee, A., Dumout, M.-J., Raghavan, V. 2014. Review: Sustainable production of hydroxymethylfurfural and levulinic acid: Challenges and opportunities. Biomass Bioenergy 72: $143-183$.

Nakamori, M., Hie, V. T., Khan, N. C., Lam, N. T., Dung, N. T., Uotsu, N., Shiomi, T., Okuhara, Y., Kise, M., Shigematsu, N., Yamamoto, S. 2010. Difructose anhydrite III enhances bioavailability of water-insoluble iron in anemic Vietnamese women. J. Nutr. Sci. Vitaminol (Tokyo). 56: 191-197.

Park, J.B., Choi, Y.J. 1996. Purification and characterization of inulin fructotransferase (depolymerizing) from Arthrobacter sp. A-6. J. Microbiol. Biotechnol. 6: 402-406.

Patterson, C., Slocum, G., Busey, R., Mesmer, R. 1982. Carbonate equilibria in hydrothermal systems: First ionization of carbonic acid in $\mathrm{NaCl}$ media to $300^{\circ} \mathrm{C}$. Geochim. Cosmochim. Acta 46: 1653-1663.

Savage, P.E. 1999. Organic chemical reactions in supercritical water. Chem. Rev. 99: 603-622.

Shigematsu, N., Okuhara, Y., Shiomi, T., Tomita, F., Hara, H. 2004. Effect of difructose anhydride III on calcium absorption in humans. Biosci. Biotechnol. Biochem. 68: 1011-1016.

Uchiyama, T., Niwa, S., Tanaka, K. 1973. Purification and properties of Arthrobacter ureafaciens inulase II. Biochim. Biophys. Acta - Enzymol. 315: 412-420.

Wang, X., Yu, S., Zhang, T., Jiang, B., Mu, W. 2015. From fructans to difructose dianhydrides. Appl. Microbiol. Biotechnol. 99: 175-188.

Yokota, A., Enomoto, K., Tomita, F. 1991. Purification and properties of an inulin fructotransferase (depolymerizing) from Arthrobacter sp. H65-7. J. Ferment. Bioeng. 72: 262265.

Yoshimoto, S., Loo, T. M., Atarashi, K., Kanda, H., Sato, S., Oyadomari, S., Iwakura, Y., Oshima, K., Morita, H., Hattori, M., Honda, K., Ishikawa, Y., Hara, E., Ohtani, N. 2013. Obesity-induced gut microbial metabolite promotes liver cancer through senecence secretome. Nature 499: 97-101.

Yoshioka, H., Shimizu, N. 2014. Characterization of the nanoscale processing of waxy rice starch using compressed hot water. Jpn. J. Food Eng. 15: 95-100.

Zhao, M., Mu, W., Jiang, B., Zhou, L., Zhang, T., Lu, Z., Jin, Z., Yang, R. 2011. Purification and characterization of inulin fructotransferase (DFA III-forming) from Arthrobacter aurescens SK 8.001. Bioresour. Technol. 102: 1757-1764. 